\section{ECONOMICS}

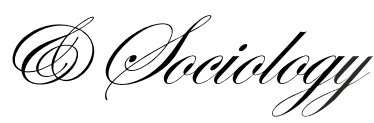

\title{
TOURIST ACTIVITY OF LGBT IN EUROPEAN POST-COMMUNIST STATES: THE CASE OF POLAND
}

Jacek Borzyszkowski, Koszalin University of Technology, Koszalin, Poland,

E-mail:jacbo@mp.pl

Received: October, 2015

1st Revision: October, 2015

Accepted: December, 2015

DOI: $10.14254 / 2071-$

789X.2016/9-1/13

\begin{abstract}
It is a common opinion that LGBT constitute a very active segment of the present-day tourist market. In the opinions of many scientists, their tourist activity is even higher than that of heterosexual people (considering both the numbers of trips and tourist expenditures). In this article, we present the tourist activity of the Polish LGBT society as an example of this segment from one of post-communist countries. In an anonymous poll, 442 people participated who represented 4 LGBT environments, i.e. gays, lesbians, bisexuals and transsexuals. We examined their tourist activity from the perspective of the destinations of their trips, expenditures etc. Thereby, the information obtained allowed us to define the tourist activity level of the Polish LGBT as compared with the whole of the Polish society and LGBT environments from other countries. The results obtained have implications for further research related to the tourist activity of LGBT.
\end{abstract}

JEL Classification: L83, Z32

Keywords: LGBT, tourist behavior, LGBT tourism, sociodemographic factors, Poland.

\section{Introduction}

Tourism is a great phenomenon of the present times. This concerns practically all the aspects of the present-day tourist market, both on the demand side and the supply side. There has been an intensive development of tourism since mid $20^{\text {th }}$ century till this day. It is estimated that this sector is one of the most dynamically developing segments of the modern economy. This phenomenon has contributed to an intensification of many studies concerning the phenomenon of tourism. Currently, an increasing involvement is being observed of those entities that operate on the tourist market in the issue of the creation of attractive products for potential recipients. It is interesting to note that it is also the sexual orientation that is becoming an element of the diversification of offers. Where does the growing interest on the part of companies and tourist organizations in the LGBT community come from? Until the late 1970s, the gay was an "invisible" segment of the tourist market, and was most frequently associated with the AIDS epidemic (Pritchard et al., 1998). This is currently changing. It is even said that LGBT tourism is one of the most attractive and fastest growing niche markets in the world, quite resistent to economic turbulences (Otero Paradela et al., 2014). According 
to the research carried out in the year 2000 by the Tourism Intelligence International, tourism of non-heterosexual people already constitutes $10 \%$ of the world tourist market. According to the data from the Gay and Lesbian Travel Association (GLTA), this is currently over $12 \%$ of the world tourist market (Borzyszkowski, 2012).

A number of factors point to the growing significance of the LGBT tourist market: both in individual countries and in the global perspective. These changes refer both to the demand side and the supply side, even in the scope of the continuously developing tourist marketing for LGBTs (Coon, 2012; Dixon, 2015). In some countries, tourist marketing is conscious and at the same time active element of the tourist policy. Several countries now have a dedicated "gay" page on their national tourism websites. The 'LGBTBritain' section on VisitBritain, lists all events, festivals, gay-friendly cities and gay history and culture (Khan, 2013, p. 14). The development of the LGBT tourist market is evident in many countries in the world. This niche has been growing really fast and preferred destinations for this community have emerged, especially in Western European countries and North America (Hughes, 2006; Clif, Forrest, 1999; Puar, 2002; Lück, 2005). In contrast to East European cities, West European cities and countries have increasingly targeted gay and lesbian travelers as part of their tourism campaigns (Köllen, Lazar, 2012, p. 64). In the so-called postcommunist states (especially in the aspect of the Middle and East Europe states), LGBT community is facing many problems, chiefly of a cultural and social nature (Barrett, Pollack, 2005).

LGBT issues in these countries are becoming more and more popular in the context of scientific studies. This phenomenon has particularly been visible over the past few years (among other Dioli, 2011; Fojtová, 2011; LaSala, Revere, 2011; Ferreira, 2013; Kuchar, Švab, 2014; Kulpa, 2014). It is interesting to note that the issue of the tourist activity of the LGBT community from these countries so far has not been the subject of any wider research, and analyses and the few existing studies are of a quite limited nature or one that hinders an accurate interpretation of the phenomenon. The study T. Köllen and S. Lazar (2012) may serve as an example here. It concerns gay tourism in Budapest yet in the context of arrival tourism in this town (mainly tourisms from West European and North American states). It is difficult to point to the phenomenon of the LGBT tourist activity in these countries. This article is aimed to a significant extent at filling up this gap. The authors are trying to indicate a model of the LGBT tourist activity in post-communist countries, analyzing the case of Polish society.

The paper starts with a survey of results of earlier investigations concerning the LGBT community tourist activity. Next, an attempt is made to compare it to the tourist activity of heterosexual individuals. Further on, the study presents a comparison between the results of the authors' own research and the reports presented by other researchers.

The purpose of this study is an attempt to assess the rate of the tourist activity of the LGBT community in Poland as well as a comprehensive analysis and assessment of their behaviors and tourist preferences in the context of selected socio-demographic factors. It was accepted that the LGBT tourist activity will be understood as at least one voluntary trip outside the permanent place of residence over the last year, dictated by individual (nonearning) goals. The rate of the tourist activity, i.e. the percentage relation of people who participate in tourism to the total of the population examined will constitute the measure of this activity (Lubowiecki-Vikuk, 2011). Tourist activity is determined by many factors. Essential factors include among others: the level of education and incomes, the profession performed and duties connected with this, age, sex and marital status (Alegre et al., 2010; Lubowiecki-Vikuk, 2011). The sexual orientation seems to be quite an intriguing factor that forms the rate of tourist activity (Hughes, Deutsch, 2010). 


\section{Tourism of LGBT}

The issue of the LGBT tourism is taken up in scientific literature in quite a wide context (Southall, Fallon, 2011). It is worth emphasizing that the issues analyzed concern different aspects of the LGBT tourism. To put it simply, one may talk about a scientific approach to the problem of the LGBT tourist market, and thereby analyze it from the perspective of the tourist supply, as well as the tourist demand. At this point, it should also be emphasized that it is only part of studies that concern the whole LGBT segment. Vast majority is limited only to selected LGBT groups and gays and lesbians in particular.

The LGBT tourist supply is an issue that is definitely more rarely taken up in scientific deliberations. One of them includes the study by H. L. Hughes (2003). Author found number of reasons for warranting or not warranting the targeting of gay markets by urban destinations. First group comprised "the group represents a new market for existing products", "they are perceived to be interested in urban tourism", "general characteristics of gays include a propensity for and frequency of travel, high travel spend, high income and education levels, an interest in culture, few family connections, and more free time". Not warranting factors comprised the following: "the characteristics are not universally applicable to all gays and lesbians", "segmentation by sexual orientation conceals other characteristics such as age, race, attitudes, and interests, which may have a stronger bearing on travel purchase patterns". The level of income is a disputed issue (Badgett, 2000). Therefore, it is important that "(..) all destinations seeking to attract LGBT customers have a duty to recognize the link between social acceptance of homosexuality, government legislation and the effects of these on their business" (Global Report..., 2010, p. 10).

Definitely more attention in scientific literature is paid to the demand side of the LGBT tourist market. A significant number of studies concern the so-called tourist motivations. It is worth emphasizing that contrary to many opinions, sexual motivations are not at all dominating in the hierarchy of the LGBT tourist motivations. Apart from this, gay and lesbian travel market is not a homogenous segment: not all wish to travel to a gay-friendly destination or take exclusively gay vacations, but certainly they wish to avoid being excluded from any destination (Pritchard et al., 1998). Moreover, according to Hughes (2005), when homosexual tourists choose their holiday destination, they are likely to take more factors into account than heterosexual tourists, such as the presence of gay space, the opportunity for socializing with other homosexuals and gay friendliness. The available scientific studies concerning tourist motivations of the LGBT community are characterized by a significant diversification regarding the place where the research is carried out, among others a sample of British gays (Clift, Forrest, 1999), gay and lesbian residents in Wales and the Netherlands and their holiday choices (Pritchard et al., 2000), the hotel experiences of gays and lesbians in the UK and in Israel (Poria, 2006), valuable resources for gay tourists in Gran Canaria (Melián-González et al., 2011). Scientific studies also highlight other aspects, e.g. diversification according to age (Hughes, Deutsch, 2010), number of tourist trips within one year (Verdugo, 2010).

A lot of attention is paid to tourist expenditures (funds spent on the purchase of tourist products and services as well as para-tourist services before and during the trip). It results from the fact that many scholars are certain of high purchasing power of the LGBT. It is stated that sexual minorities spend during the trip 30\% more than other tourists (Jedrysiak, 2008). In relation to gay and lesbian tourism, it might be suggested that they travel abroad more frequently than heterosexuals because their higher discretionary income makes it possible (Haslop et al., 1998; Binnie, Valentine, 1999; Philipp, 1999; Stuber, 2002).

An analysis of the trip destinations characteristic of the LGBT segment is inseparably connected with the tourist activity issue. Destination choice is a process whereby travelers analyze places and search for the best attributes in them, i.e. they discriminate destinations 
based on risks and desirable characteristics (Cooper et al., 2005; Hughes, 2006). As stated by S. L. Herrera and D. Scott, in spite of an increasing tolerance towards the LGBT segment, gays often feel "forced" to go to places where they can freely express their sexual identity (Monterrubio, 2009). What is more, some of them travel among others, due to the fact that they do not want their psycho-sexual otherness to be recognized in the place of their residence. A trip to a specific destination helps them to freely display their homosexual identity (Hughes, 1997). An aversion is frequently observed towards this segment of the tourist market: both on the part of the authorities of big cities and local communities (Morris, Carney, 2010). Even in countries where homosexuality is legal, gay and lesbian tourists might face discrimination, social disapproval and prejudices.

\section{Tourist activity of LGBT and heterosexual travelers}

Many differences can be demonstrated between LGBT tourist trips and heterosexual travellers. Of course, a certain number of features will be common. It results, among others, from the division of the tourist movement itself (duration, kind, types). As already mentioned, in literature, a lot of attention is paid to the issue of tourist motivations. It is interesting to note that according to Hughes (2002), Pritchard et al. (2000) and Clift and Forrest (1999), men regardless of their sexual orientation have the same motivations to go on holidays. This is also emphasized by J. C. Monterrubio (2009), according to whom the travel motivations of gays and lesbians do not fundamentally differ from those of heterosexual people. Some authors, however, express different opinions concerning this issue. While for heterosexual people the tourist trip is of a voluntary nature, and so they select the destination they prefer (e.g. in the respect of the climate, nature etc.), LGBT are "condemned" to the choice of a specific location in certain aspects. It is quite accurately emphasized by R. M. Khan (2013) analyzing the case of tourist activity of gays. The researcher talks about a gay-identity travel motivation model, where four basic elements are distinguished, i.e. need for safety, escapism through anonymity, gay-identity acceptance and gay-identity affirmation. To a significant extent, these elements define the basic motivations of the tourist trips of gays (LGBT). It was also observed that in the case of gays, there is quite a strong need of the companionship of other homosexuals and staying in gay-friendly places and facilities. What is worth noting, gays are significantly more prone to establish new sexual contacts during trips than heterosexuals. This was observed by H. L. Hughes (2006), who, on the one hand, thinks that the trips of heteroand homosexual people have a part of joint motives, i.e. social interactions, regeneration, selffulfilment, feeling of freedom, strengthening of one's ego or prestige. On the other hand, gays have a strong motivation of staying with other gays and possessing access to places that are friendly to them (Melián-González et al., 2011).

Another and quite controversial problem is the question of interacting with the locals. According to Crompton (1979), Mathieson and Wall (1987) there is similarity between the two segments. There are some academics (Hindle, 1994; Taylor, 1997; Grossmann, 1998), however, who do state, that homosexual tourists are more keen than the straight tourists to socialize with the locals. Another similarity between the two segments is that they both are likely to visit friends and relatives during their travels (Mathieson, Wall, 1987; Hanefors, 2010).

One of the factors determining the development of modern tourism is an increasing level of education. It appears that in many cases, the LGBT community definitely has better education than heterosexual people. For example, in the USA, 7\% of the LGBT community possesses a scientific degree of doctor, with less than $1 \%$ among heterosexual people (Pritchard et al., 1998). The majority of the LGBT people also have another advantage. It is evident from the research carried out by Community Marketing Inc that $76 \%$ of American gays and lesbians possess a valid passport, while the average for US residents is ca. $30 \%$. 
There are considerably more differences between homosexual and heterosexual people, including the levels of tourist expenditures. According to the Travel Industry Association (TIA), during a tourist trip (in small groups) gays spend on the average USD 3,070, while heterosexual people spend USD 2,870 (Morris, Carney, 2010).

To conclude, trips realized by the LGBT community and heterosexual people exhibit many similarities, although in many studies the questions are raised of clearly visible differences. Opinions on this issue are quite divided.

\section{Methodology}

In the exploration of the phenomenon under examination, the method of induction was applied, and further the method of CAWI (Computer-Assisted Web Interviewing): based on computer aided data collection technique (interview). An assumption was accepted that the LGBT environment possesses a significant share in the penetration of the internet (Benotsch et al., 2011). On the basis of the author's own research and a review of literature in the area of research issues, an attempt was made to formulate general conclusions concerning (expected) behaviours and tourist preferences of the LGBT environment in Poland. In general, the behaviors of this type are realized in leisure time.

By choosing the CAWI method, it was the authors' intention to maintain the intimate space of the environment examined. Due to the fact that non-heterosexual people constitute research group that is hard to access, the features of the post-modern society and globalization were taken into consideration; where the Internet is gaining significance in daily life, and at the same time it is becoming a tool of modern interdisciplinary research (Zając, Batorski, 2009). Apart from that, more comfortable conditions, i.e. time that is convenient to the respondent, are favourable to the participation in the research. Additionally, the capital intensity of the realization of this type of research does not pose greater limitations. The CAWI method is not an ideal research method. In Poland, $33.1 \%$ of households still do not have an Internet access (Batorski, 2013). However, an assumption was accepted that the LGBT environment possesses a significant share in the penetration of the Internet. An electronic questionnaire was constructed and an Internet address was assigned to it, which in the form of an invitation to the participation in the research was made available on special dedicated Internet forums, community and dating portals as well as on the official websites of selected associations and organizations that act for the LGBT environment.

442 people participated in an anonymous online research. They were the representatives of 4 LGBT environments, i.e. gays, lesbians, bisexuals and transsexuals. It is worth emphasizing that it is the first research of this type in Poland that covers all the representatives of LGBT communities. The research group is not a representative sample; in spite of the shortage of reliable LGBT socio-demographical data, an effort was taken to carry out the research of this kind bearing in mind its limitations but also the awareness that the initiative begun may be continued in the form of further research in this area owing to the emerging studies that are increasing in numbers concerning the social and cultural issues of the "gender" sexual identity. This research is not of a decisive nature, while it is to provide some explanations.

The research was carried out over a period of three months (January to March 2014), and was completed the moment the winter tourist season finished. The Internet questionnaire form included questions concerning participation in tourism over the last year. Questions concerned trips (participation in at least one tourist trip in the period examined), trip destinations (national, European, extra-European trips), their duration (1 day, 2-4 days, 5 and more days), purpose (holiday and recreation, visits of relatives and/or friends, business, shopping, tourist, health), the way in which it was organized (on one's own, with a travel 
agency) and the level of tourist expenditures (PLN 2,000.00 and below, PLN 2,000.00 - PLN $4,000.00$, PLN 4,000.00 and more). They were also asked to provide information concerning tourist behaviors such as: with whom they travel (alone, with their partner, with their friend, with their family), what places of accommodation and means of transport they choose, as well as the importance degree of the occurrence of specified conditions of trips: the presence of gay-friendly infrastructure in the vicinity, the possibility of safe rest as an LGBT person, the possibility of contacts with other people from the LGBT environment, an adequate and tolerant attitude on the part of the service/personnel of the lodging facility to people from the LGBT environment.

Apart from the information concerning participation in tourism, data was collected concerning the sex, age, education, place of residence, the profession performed, the civil and legal statues, the sexual orientation and the income of the people examined. Given the compiled data, the respondents were classified into individual categories (Table 1).

Table 1 . Tourist activity of the population $(n=442)$ examined according to category of sociodemographic variables

\begin{tabular}{|c|c|c|c|c|c|c|}
\hline & \multirow[b]{2}{*}{ Variables } & \multicolumn{2}{|c|}{ Population } & \multirow{2}{*}{$\begin{array}{c}\text { National } \\
\text { tourist activity } \\
\text { (in \%) }\end{array}$} & \multirow{2}{*}{$\begin{array}{l}\text { European } \\
\text { tourist activity } \\
\text { (in \%) }\end{array}$} & \multirow{2}{*}{$\begin{array}{l}\text { Extra-European } \\
\text { tourist activity } \\
\text { (in \%) }\end{array}$} \\
\hline & & $\mathrm{n}$ & $\%$ & & & \\
\hline & 1 & 2 & 3 & 4 & 5 & 6 \\
\hline \multirow{2}{*}{ Sex } & Male & 227 & 51.4 & 66.5 & 48.9 & 15.4 \\
\hline & Female & 215 & 48.6 & 83.7 & 55.8 & 14.0 \\
\hline \multirow{5}{*}{ Age } & $18-19$ & 100 & 22.6 & 71.0 & 37.0 & 11.0 \\
\hline & $20-29$ & 223 & 50.5 & 76.7 & 55.2 & 12.1 \\
\hline & $30-39$ & 84 & 19.0 & 70.2 & 57.1 & 16.7 \\
\hline & $40-49$ & 26 & 5.9 & 88.5 & 69.2 & 38.5 \\
\hline & $50+$ & 9 & 2.0 & 77.8 & 55.6 & 33.3 \\
\hline \multirow{5}{*}{$\begin{array}{l}\text { Place of } \\
\text { residence }\end{array}$} & Village & 28 & 6.3 & 60.7 & 57.1 & 14.3 \\
\hline & $\begin{array}{l}\text { Town up to } 20 \\
\text { thousand residents }\end{array}$ & 39 & 8.8 & 76.9 & 28.2 & 0.0 \\
\hline & $\begin{array}{l}\text { Town from } 21 \\
\text { thousand to } 100 \\
\text { thousand residents }\end{array}$ & 81 & 18.3 & 65.4 & 54.3 & 16.0 \\
\hline & $\begin{array}{l}\text { Town from } 101 \\
\text { thousand to } 500 \\
\text { thousand residents }\end{array}$ & 97 & 21.9 & 88.7 & 64.9 & 17.5 \\
\hline & $\begin{array}{l}\text { Town above } 500 \\
\text { thousand residents }\end{array}$ & 197 & 44.6 & 73.6 & 49.2 & 15.7 \\
\hline \multirow{3}{*}{ Education } & primary/vocational & 56 & 12.7 & 75.0 & 25.0 & 1.8 \\
\hline & secondary & 190 & 43.0 & 73.2 & 47.4 & 14.2 \\
\hline & higher & 196 & 44.3 & 76.5 & 64.8 & 18.9 \\
\hline \multirow{3}{*}{$\begin{array}{l}\text { Civil and } \\
\text { legal status }\end{array}$} & $\begin{array}{l}\text { Person living } \\
\text { alone }\end{array}$ & 242 & 54.8 & 74.0 & 44.6 & 13.2 \\
\hline & $\begin{array}{l}\text { Person possesses } \\
\text { partner of the same } \\
\text { sex, they live } \\
\text { together }\end{array}$ & 91 & 20.6 & 82.4 & 60.4 & 22.0 \\
\hline & $\begin{array}{l}\text { Person possesses } \\
\text { partner of the } \\
\text { same sex, they live } \\
\text { separately }\end{array}$ & 98 & 22.2 & 70.4 & 61.2 & 11.2 \\
\hline
\end{tabular}


RECENT ISSUES IN SOCIOLOGICAL RESEARCH

\begin{tabular}{|c|c|c|c|c|c|c|}
\hline & 1 & 2 & 3 & 4 & 5 & 6 \\
\hline & $\begin{array}{l}\text { Heterosexual } \\
\text { relationship }\end{array}$ & 11 & 2.5 & 72.7 & 72.7 & 18.2 \\
\hline \multirow{6}{*}{$\begin{array}{l}\text { Social and } \\
\text { professional } \\
\text { group }\end{array}$} & Pupil/student & 236 & 53.4 & 77.5 & 47.5 & 12.7 \\
\hline & $\begin{array}{l}\text { Person runs their } \\
\text { own business }\end{array}$ & 30 & 6.8 & 93.3 & 83.3 & 43.3 \\
\hline & $\begin{array}{l}\text { Permanent } \\
\text { professional work }\end{array}$ & 168 & 38.0 & 71.4 & 51.2 & 11.9 \\
\hline & Casual work & 44 & 10.0 & 86.4 & 54.5 & 13.6 \\
\hline & $\begin{array}{l}\text { Senior } \\
\text { citizen/pensioner }\end{array}$ & 4 & 0.9 & 100.0 & 25.0 & 25.0 \\
\hline & $\begin{array}{l}\text { Unemployed } \\
\text { person }\end{array}$ & 16 & 3.6 & 62.5 & 62.5 & 6.3 \\
\hline \multirow{3}{*}{$\begin{array}{l}\text { Sexual } \\
\text { orientation }\end{array}$} & Homosexual & 335 & 75.8 & 74.3 & 52.2 & 15.2 \\
\hline & Bisexual & 103 & 23.3 & 77.7 & 52.4 & 12.6 \\
\hline & $\begin{array}{l}\text { Transsexual } \\
\text { person }\end{array}$ & 4 & 0.0 & 50.0 & 50.0 & 25.0 \\
\hline \multirow{6}{*}{ Income } & $\begin{array}{l}\text { Up to PLN } 1500 \\
\text { ( } 380 \text { USD) }\end{array}$ & 146 & 33.0 & 78.8 & 43.8 & 8.2 \\
\hline & $\begin{array}{l}\text { PLN 1501-2500 } \\
\text { (381-630 USD) }\end{array}$ & 97 & 21.9 & 77.3 & 39.2 & 7.2 \\
\hline & $\begin{array}{l}\text { PLN 2501-3500 } \\
\text { (631-885 USD) }\end{array}$ & 60 & 13.6 & 68.3 & 70.0 & 21.7 \\
\hline & $\begin{array}{l}\text { PLN 3501-4500 } \\
\text { (886-1140 USD) }\end{array}$ & 35 & 7.9 & 88.6 & 77.1 & 25.7 \\
\hline & $\begin{array}{l}\text { Over PLN } 4500 \\
\text { (1141 USD) }\end{array}$ & 49 & 11.1 & 67.3 & 79.6 & 40.8 \\
\hline & No incomes & 55 & 12.4 & 65.5 & 38.2 & 7.3 \\
\hline
\end{tabular}

Source: own study based on research $n=442$.

The connections between the tourist activity and the selected tourist behaviours and those variables that characterize the socio-demographic structure of the people examined were established by means of the chi-square test $\left(\mathrm{Chi}^{2}\right)$. The analyses were performed using the SPSS 21 statistical package. In the assessment of the significance of the effects, the significance level $p<.05$ was accepted, and only those effects were presented in the study.

\section{Results}

Thanks to an analysis of the data available, it was possible to demonstrate the tourist activity of the population examined according to different criteria. The authors conducted the analysis based on the criteria accepted in Table 1, and they were included in three groups, i.e. national tourist activity, foreign European activity and foreign extra-European activity. Thereby, the results obtained allowed the authors to determine which destinations (understood as the space of tourist activity) were selected by the Polish LGBT community. Furthermore, the division accepted (national, European, extra-European trips) could initially define the tourist activity level of the individual groups, and hence their "purchasing power". It is a wellknown fact that in the majority of cases, national tourism is selected by individuals and segments considering its price attractiveness. Trips to extra-European destinations constitute the most expensive forms of tourist activity.

The information presented in Table 1 covers a diversification of the tourist activity of the LGBT community examined in the context of national and foreign trips. First of all, it was 
demonstrated that a decrease was observed of the tourist activity in connection with the distance from a given destination practically in all the cases (criteria). This means that the highest values were reported in the case of activity in national tourism and the lowest ones in foreign extra-continental (i.e. extra-European) tourism. The first and most important conclusions from Table 1 may include the following: a higher participation of women than men in tourist trips, the highest tourist activity in the group of those aged 40-49 (which may point to a stable material status), an increase of tourist activity together with the size of the permanent place of residence (with the highest values in towns with 101-500 thousand residents). Furthermore, it was observed that those people who remain in a relationship (including those who reside together), those who run their own businesses and, in the case of national tourism: senior citizens and pensioners, are the most active people as regards tourism. It is of significant importance that an increase in the average income of the examined respondent has an influence not only on the tourist activity rate but also on the tourist space. It was found that the higher the income is, the more distant (i.e. extra-European) destinations are chosen by the respondents.

The sex was the factor which possessed an essential connection $\left(\mathrm{Chi}^{2}=17.37 ; \mathrm{df}=1\right.$; $p<.000)$. It is worth observing that the tourist activity of women was higher than that of men. As many as $83.7 \%$ of the whole number of women declared their participation in tourism; in the structure of men, this percentage was $66.5 \%$ (Table 1). Furthermore, the respondents' permanent place of residence exerts an influence on traveling in Poland $\left(\mathrm{Chi}^{2}=16.88 ; \mathrm{df}=4\right.$; $p<.005)$. The greater the number of residents at a given place, the greater their activity in this scope. $5.1 \%$ of those polled left villages, $9.1 \%$ of those polled left a town with up to 20 thousand residents, $16.0 \%$ of those polled left town a with $20-100$ thousand residents, $26.0 \%$ of those polled left a town with $100-500$ thousand residents and $43.8 \%$ of those polled left town with over 500 thousand residents.

The membership in a social and professional group of those examined including pupils/students $\left(\mathrm{Chi}^{2}=6.41 ; \mathrm{df}=2 ; p<.05\right)$, people who run their own businesses $\left(\mathrm{Chi}^{2}=14.86\right.$; $\mathrm{df}=2 ; p<.005)$, those who do odd jobs $\left(\mathrm{Chi}^{2}=8.35 ; \mathrm{df}=2 ; p<.05\right)$, senior citizens/pensioners $\left(\mathrm{Chi}^{2}=8.93 ; \mathrm{df}=2 ; p<.05\right)$ and unemployed people $\left(\mathrm{Chi}^{2}=9.56 ; \mathrm{df}=2 ; p<.05\right)$ forms and diversifies the level of participation in national tourism.

At the same time, every second person examined - more frequently $\left(\mathrm{Chi}^{2}=13.92\right.$; $\mathrm{df}=4 ; p<.05)$ aged 20-29 (53.2\%), 30-39 (20.8\%), 18-19 (16.0\%) rather than 40-49 (7.8\%) and $50+(2.2 \%)$ was on a tourist trip to European countries. These were people holding university degrees $\left(\mathrm{Chi}^{2}=30.84 ; \mathrm{df}=2 ; p<.000\right)$ rather than with secondary or primary/vocational education $(55.0 \%, 39.0 \%, 6.1 \%$ respectively) and people with various civil and legal statuses $\left(\mathrm{Chi}^{2}=13.09 ; \mathrm{df}=3 ; p<.005\right)$ : singles $(46.8 \%)$, those who have a partner of the same sex living separately $(26.0 \%)$ and those who have a partner of the same sex - living together $(23.8 \%)$ rather than people who live in heterosexual relationships $(3.5 \%)$.

Important statistical connections were also observed with the size of the places of residence of those polled $\left(\mathrm{Chi}^{2}=16.43 ; \mathrm{df}=4 ; p<.005\right)$. Similarly as in the case of national trips, these dependences are more clear in comparison with respondents from towns with up to 20 thousand residents, where $4.8 \%$ left, and from towns with over 500 thousand residents: where $42.0 \%$ went on a trip to some place in Europe.

Statistical connections appeared to be quite intriguing indeed between European trips and the level of net monthly incomes of the respondents $\left(\mathrm{Chi}^{2}=46.10 ; \mathrm{df}=5 ; p<.000\right)$. Those who declare no income $(9.1 \%)$ travel less frequently, and those people whose level of incomes was PLN 3.501.00 - PLN 4.500 .00 (11.7\%) travel only rarely. The group of respondents who obtain incomes on the level of PLN 1,500.00 and below (27.7\%) and PLN $1,501.00$ - PLN 2,500.00 (18.2\%) turned out to be the most numerous fraction that undertakes tourist activity in European countries. Those polled who obtain incomes at the level of PLN 
1,501.00 - PLN 2,500.00 and PLN 4,500.00 and more also traveled in Europe (16.5\% and $16.9 \%$ respectively).

The social and professional status of the respondents has an influence on the level of incomes, and this translates into trips to Europe. In this respect, it was observed that the activity of this kind occurs due to the fact of being a pupil/student $\left(\mathrm{Chi}^{2}=6.23 ; \mathrm{df}=2 ; p<.05\right)$ and a person who runs their own business $\left(\mathrm{Chi}^{2}=12.57 ; \mathrm{df}=2 ; p<.005\right)$.

$14.7 \%$ of those polled went outside Europe in the analyzed period. These were more frequently $\left(\mathrm{Chi}^{2}=16.74 ; \mathrm{df}=4 ; p<.005\right)$ people aged $20-29(41.5 \%), 30-39(21.5 \%), 18$ $19(16.9 \%), 40-49(15.4 \%)$ rather than $50+(4.6 \%)$. In this case, too, essential statistical connections were observed. This is a reference to the level of education of those polled with their trips outside the European continent $\left(\mathrm{Chi}^{2}=10.20 ; \mathrm{df}=2 ; p<.05\right)$. Respondents with primary/vocational education (1.5\%) rarely took up trips of this kind as compared to those with secondary $(41.5 \%)$ or higher education $(56.9 \%)$. The level of monthly net incomes $\left(\mathrm{Chi}^{2}=43.99 ; \mathrm{df}=5 ; p<.000\right)$ as well as the social and professional status of those polled: above all, those who run their own business $\left(\mathrm{Chi}^{2}=21.54 ; \mathrm{df}=2 ; p<.000\right)$ is also responsible for their level of participation in extra-European tourism. Those who possess incomes at the level of PLN 4,500.00 and over (30.8\%), PLN 2,501.00 - PLN 3,500.00 (20.0\%), PLN 1,500.00 and below $(18.5 \%)$ went on trips relatively more frequently as compared with those whose incomes were at the level of PLN 3,501.00 - PLN 4,500.00 (13.8\%), PLN 1,501.00 - PLN $2,500.00(10.8 \%)$ and those who did not have any incomes $(6.2 \%)$.

The tourist activity of those examined is closely correlated with the level of tourist expenditures. Almost 31\% of the respondents assigned an amount of PLN 4,000.00 and over for this purpose. $22.8 \%$ of the people examined spent PLN 2,001.00 - PLN 4,000.00 and the remaining fraction $(46.3 \%)$ assigned the lowest amount for tourist purposes, i.e. PLN $2,000.00$ and below. In this scope, essential statistical connections were observed, which focus on such factors as age $\left(\mathrm{Chi}^{2}=51.39 ; \mathrm{df}=8 ; p<.000\right)$, education $\left(\mathrm{Chi}^{2}=45.74 ; \mathrm{df}=4\right.$; $p<.000)$, place of permanent residence $\left(\mathrm{Chi}^{2}=16.74 ; \mathrm{df}=8 ; p<.05\right)$, incomes $\left(\mathrm{Chi}^{2}=161.37\right.$; $\mathrm{df}=10 ; p<.000)$, civil and legal status $\left(\mathrm{Chi}^{2}=19.07 ; \mathrm{df}=6 ; p<.005\right)$, a social and professional group with reference to a pupil/student $\left(\mathrm{Chi}^{2}=24.94 ; \mathrm{df}=4 ; p<.000\right)$, people who run their own businesses $\left(\mathrm{Chi}^{2}=36.81 ; \mathrm{df}=4 ; p<.000\right)$, people who take permanent professional work $\left(\mathrm{Chi}^{2}=10.41 ; \mathrm{df}=4 ; p<.05\right)$ and unemployed people $\left(\mathrm{Chi}^{2}=14.09 ; \mathrm{df}=4 ; p<.05\right)$.

Different factors contribute to the purposes of tourist trips and, as a consequence, the choice of the place of the tourist rest of those examined (Figure 1). Among the most important ones, the respondents included the proper tolerant approach of the staff/personnel of the lodging facility to people from the LGBT environment (very important and important $69.7 \%$ ) and possibility of safe recreation the spot offers for LGTB person (very important and important $66.3 \%$ ). The presence of infrastructure with the reputation of being LGBT-friendly (bars, restaurants, hotels, discotheques, saunas etc.) in the vicinity of the place of their stay ( $12.7 \%$ and $16.3 \%$ respectively) was of little or no significance to those examined, and not much great significance was attached to the possibility of contact with other LGBT people (10.2\% and $15.8 \%$ respectively). In total, $28.3 \%$ of the respondents demonstrated an indifferent attitude to the analyzed factors. 


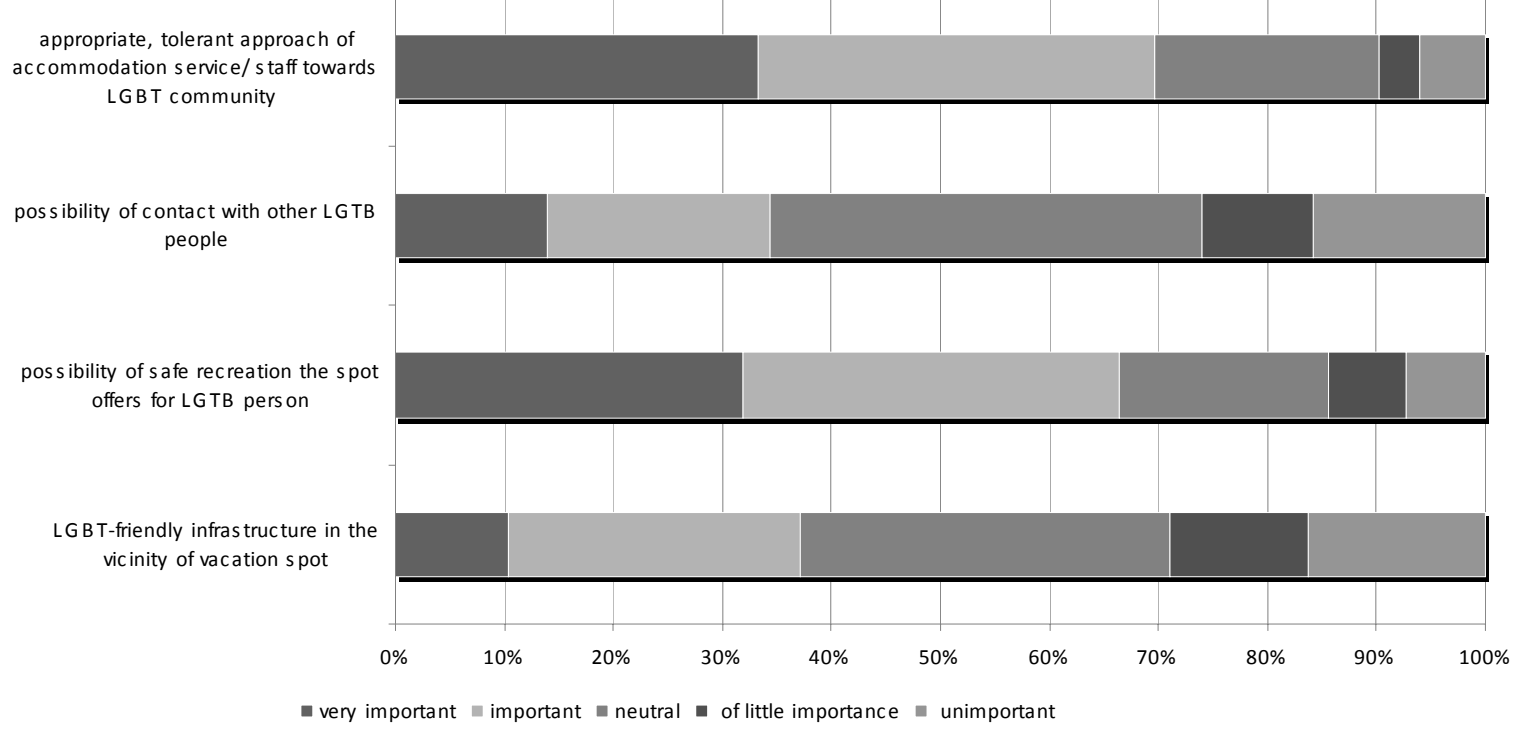

Figure 1. Level of significance of the factors affecting the choice of holiday destinations among the respondents

Source: own study based on research $n=442$.

\section{Discussion and Implications}

Further part of the study includes an attempt to compare the results of the author's own research with reports from other researchers. The authors accepted two fundamental goals, i.e. an analysis of the LGBT tourist activity rate in Poland in comparison with the whole of the Polish society and a comparison of the LGBT tourist activity in Poland with foreign LGBT environments.

\subsection{The group examined and the Polish society}

In the first case, the primary source of information was statistical data that is prepared on annual basis by the Ministry Sports and Tourism, which has been performing the function of the proper department for tourism in Poland since the year 2007. In other words, this ministry performs the function of the so-called national tourism administration: NTA (Borzyszkowski, 2005). It is worth noting that a thesis is confirmed that LGBT tourist activity is higher than that of the whole of the society. In the case of the group examined, it was 89.4\% and for the Polish society: 56\% (Podróże Polaków..., 2014, p. 1). A fundamental difference is observed in the scope of the so-called national tourist activity: in the case of LGBT, the percentage of those participating was $75 \%$, and in the case of the Polish society: 46\% (Podróże Polaków..., 2014; Łaciak, 2013).

Certain similarities were revealed when analyzing the rate of tourist activity in the context of selected socio-demographic features. In relation to the place of residence, in both cases (LGBT and the whole of society), the following dependence was observed: the greater the number of the residents of a given place is, the greater their activity is in this area. Both in the case of LGBT and the whole of the Polish society, a slightly larger tourist activity of women is noticeable. As regards the Polish society, the advantage of women is 1.9 percentage points (Laciak, 2013), and in the LGBT examined, this is as many as 17.2 percentage point (Table 1). 
A similar dependence was observed in the case of tourist activity related to incomes: the higher the income, the greater the tourist activity. In the case of the Polish society, this was not stated in numbers. The research carried out in the year 2012 on a group of 1,000 people referred to three definitions of the financial standing of the respondents, i.e. "good", "average" and "bad". In the first group, the tourist activity was $86.1 \%$ of the respondents, in the second group: $49.2 \%$, in the third group: $27.0 \%$ (Laciak, 2013). Thereby, it is confirmed that incomes constitute the fundamental factor that determines the tourist activity, regardless of sexual preferences. The situation is practically identical as concerns education: here, positive correlation can be seen, i.e. the higher education is, the greater the tourist activity is. In the case of the Polish society as a whole, higher values were obtained for people with university degrees, i.e. 87.4\% (Laciak, 2013).

According to the estimates covering the year 2012, it is accepted that the expenditures of the Polish LGBT on tourist trips amounted to USD $3.7 \mathrm{bn}$., and the average expenditures per one person: USD 1,869 (Global Report..., 2010). It was assessed for the LGBT group examined that on average, one person spends ca. PLN 2,700.00 (i.e. ca. USD 850.00) on tourist trips annually. A substantial difference is observed between the research results obtained and the estimates above. However, the authors are of the opinion that the first data (i.e. USD 1,869.00) is clearly inflated. This follows from the fact that in the year 2011, the total expenditures of the whole of the Polish society on tourism were assessed to the amount of ca. USD 14 billion (Raport o stanie..., 2013). Taking into account the fact that the LGBT community constitutes ca. 5-6\% of the Polish people, it is difficult to agree that this part of the society spends a total of over $26 \%$ of all the tourist expenditures (i.e. USD $3.7 \mathrm{bn}$. out of USD 14 bn.). Even if it is accepted a priori that expenditures on the part of LGBT are on average higher than those by heterosexual people, they certainly are not in such proportions. Thereby, the authors believe that the data obtained from the research (i.e. the average annual value of USD 850.00) is definitely more accurate. However, it is difficult to relate this data to the average expenditures on the part of Polish people on tourism. The available statistical data allows only to assess the average tourist expenditures of the Polish people divided into national (long-term only) and foreign national trips. In the first case, they amount to USD 350.00, and the second: USD 940.00 (Podróże Polaków..., 2014). Thus, it is impossible to assess the general average expenses related to tourism of the average Polish citizen. It results from the fact that part of the society participates, in a given year, both in national and foreign tourist movement. Nevertheless, the authors believe that the average expenditures of the Polish LGBT society can be higher than the whole of the society. All the more so as this average (USD 850.00) definitely comes closer to the value of foreign expenditures which obviously are definitely higher than the national ones.

To conclude, it can be explicitly stated that the tourist activity of the Polish LGBT environment is similar to that of the Polish society in many aspects. This mainly concerns the destinations: both at home and abroad. Large similarities were also observed in the case of the influence of specified socio-demographic factors on this type activity, including education and the place of residence. The only clear and noticeable difference concerned the rate of tourist activity: in this case, a clear advantage of LGBT was observed over the total of the Polish society. At the same time, it was observed that the high rate of the LGBT tourist activity is comparable to the level of tourist trips and leisure time made by Polish singles (Lubowiecki-Vikuk, 2011; Biernat, Lubowiecki-Vikuk, 2012; Lubowiecki-Vikuk, 2014).

\subsection{The group examined and other LGBT environments}

A comparative analysis of the tourist behaviors of the Polish LGBT in relation to foreign LGBT environments is of an essential significance to the arrangement of this study. 
The initial assessment allows to accept an assumption that there are a number of similarities between both groups. An interesting observation is provided by an analysis of the frequency of trips. In the case of the group examined, it is observed that over half $(55 \%)$ of those polled undertook tourist activity in the country more often than once. This is an average of 5.6 trips within the last year. Similarity, according to the CMI's 12th annual gay \& lesbian tourism study CMI's, Community Marketing (16 ${ }^{\text {th }}$ Annual Gay..., 2011), the average number of annual tourist trips was ca. 5.0. Both quantities are very similar to one another.

The results presented of the research carried out on a Polish LGBT group demonstrated that essential motives and purposes of trips include the following: leisure and recreation, visiting relatives and/or friends and sightseeing. According to Clift and Forrest (1999), an integration with the gay community and sex, learning about the culture and visiting monuments, comfort and relaxation are the most important motives of travelling for gays.

Frequently voiced statement that LGBT trips have strictly erotic or sexual overtones seems to be a groundless over-interpretation. Having sex is not the most important (if any) motive of traveling for gays (and thereby it can be assumed that this is true of the remaining LGBT segments). In the course of the author's own research, it was found that only $0.2 \%$ of the respondents included sexual purposes as the motif of their travels. This is confirmed by the results of research carried out by Clift and Forrest (1999) on a group of over 500 British gays. It is evident that an "opportunity to have sex" ranked at $9^{\text {th }}$ position only $(29.3 \%$ of replies) among the motives of the greatest significance. According to other studies carried out in relation to a group of 4,387 people who represent the LGBT community, it was only for $10.9 \%$ of them that a "sexual love affair" was of an essential significance as a motive of travelling (for $21.6 \%$ : a certain influence, for $67.5 \%$ : without any influence) $\left(16^{\text {th }}\right.$ Annual Gay..., 2011).

Safety is of an essential significance in relation to LGBT trips. According to the research by Roth (2010), it was demonstrated that with the use of the ranking method (in the scale of $0-5$ ), it was found that " 1 " (a little essential factor) - was indicated by $5.6 \%$ gays and $3.8 \%$ lesbians, " 2 " - by $4.2 \%$ and $3.7 \%$ respectively, " 3 " - by $25.4 \%$ and $20.4 \%$, " 4 " $-39.1 \%$ and $40.9 \%$, "5" $-25.7 \%$ and $31.3 \%$ (Roth, 2010). Similar results were observed in research related to the Polish LGBT. $31.9 \%$ indicated it as a "very important" factor and $34.4 \%$ as "important".

Furthermore, available research results demonstrate that facilities and an atmosphere that are appropriate for LGBT (sometimes defined as gay-friendly) are of an essential importance to a significant percentage. One should agree with the thesis proposed by Visser $(2008$, p. $1355 ; 2010)$ that homosexual people most likely to create and maintain exclusive gay leisure space sought out leisure in heterosexual leisure spaces. However, whether people are gay or not, or are required to edit behaviour, is beyond the domain of interest of those engaging these transient leisure spaces (Visser, 2003, p. 136). As stated by Clift and Forrest (1999, p. 620), gay culture and venues are of an important significance to $39.1 \%$ of respondents. The research by Melián-González et al. (2011) carried out in the year 2007 in Gran Canaria on a sample of 346 gays demonstrated that the significance of the so-called gay scene $(84.4 \%)$ ranked on the second position in the hierarchy of those factors, while gayfriendly environment ranked on the fourth position $(70.2 \%)$. In the case of the group examined, this feature was not of such a large significance: $37.1 \%$ indicate importance of gayfriendly infrastructure $(10.4 \%$ - very important, $26.7 \%$ - important $), 34.4 \%$ indicate the importance of contacts with other LGBT members during the trip $(14.0 \%$ - very important, $20.4 \%$ - important). Tolerant approach to LGBT including that on the part of the hotel staff is of a greater significance to the respondents. $69.7 \%$ of the respondents indicated an importance of this factor (33.3\% - very important, 36.4\% - important). The above findings may demonstrate that it is not so much service or infrastructure conveniences that are important for 
the respondents as tolerance. It is certainly a consequence of the fact that in many cases Polish LGBT environment is confronted with the lack of tolerance (in schools, at work, in public places). Hence, this factor is of such an important significance during a tourist trip. One may agree with B. M. Rink (2013) as concerns the question of the need to create special 'pink maps' that show LGBT friendly places.

It is not only scientists that should be inspired by the research results presented to conduct further analyses in relation to the problem examined. It seems that far more important implications should concern those entities on the market that offer tourist services (including recreation and sports). It becomes evident that the Polish LGBT community is quite an active segment of the tourist market. Their tourist behaviors and motivations do not, in fact, diverge from those of the rest of the society. Hence, there is no real need to prepare any special offers and tourist products for LGBT. For them, it is first of all the sense of security and expression of tolerance that matters. The owners of tourist companies should make use of these conclusions. The so-called destination management organizations (DMO), that is those entities which are responsible for the creation and development of competitive destinations (local, regional and national ones) should play an important role (Borzyszkowski, 2011; 2014). An appropriately prepared activity (including promotional actions) can bear fruit in the creation of an image of a given destination as being LGBT friendly.

\section{Limitations and Future Research}

The following findings are the value of the authors' own research: the rate of the LGBT community tourist activity is affected by the analysed societal and demographic factors, i.e. (1) the tourist behaviour of the presented community is most often reflected in domestic travel, which is especially affected by the respondents' affiliation with a certain social and/or professional group, (2) tourist trips are taken more often by women, large citydwellers and respondents with high incomes, (3) young people with university education are more inclined to travel to tourist destinations in Europe. Moreover, there are other factors that have an impact on the selection of a tourist destination. The persons surveyed declare that they attach particular importance to proper tolerance on the part of the lodging facility staff/personnel towards people from the LGBT environment and appreciate the opportunity for safe recreation a given place offers to an LGTB individual.

This study has certain limitations. In the methodological perspective, the authors used the CAWI research method. As previously indicated, it has specific imperfections. Furthermore, one of the features that are characteristic of the Polish LGBT segment is its heterogeneity. Construction of a model of tourist behaviours for this market segment based solely on socio-demographic factors is not fully complete and justified. Obstacles arise also from the difficulties related to the comparison of the individual results. This concerns for example comparisons between the results obtained and the statistical data for the whole of the Polish society. There is a similar situation in the case of comparisons related to the Polish LGBT and this environment in other countries.

The deliberations presented herein should act as an inspiration for further thorough analyses. This fundamentally concerns several spheres. Firstly, in the case of the Polish LGBT, the activity of various environments whose activity could bring about a number of benefits for the issues examined should be increased. This concerns above all scientists who represent various sciences and scientific fields (economic, social, humanities etc.). Significant contribution to studying this subject matter more thoroughly should be made by those environments that are related to LGBT (including the most important associations and other non-government organizations). It was noted that in the case of the Polish market, shortage of analyses of this type is evident; what is more, there is no cooperation between individual 
entities, e.g. research and non-government institutions. The Polish LGBT tourist market is little visible and is practically omitted in scientific studies and evaluations. The analysis presented demonstrated that it is quite an active segment in the area tourism. It can also be assessed that its significance will be increasing.

The second question related to future research should concern its realization in substantially wider spatial scope. As mentioned above, studies on the subject of the LGBT community (and much less the tourist market) are fragmentary in post-communist countries. The authors emphasize the significance of this type studies for many scientific disciplines. They call for the need of the realization of this type research in other Middle and East European countries. They would enable a precise determination not only of the significance of LGBT on the tourist market but, what is essential, a comparison of the LGBT activity from those countries with the environments that come from the states of Western Europe or North America.

This research requires not only a correct selection of an LGBT sample (which is an extremely difficult task) but above all an inter-disciplinary scientific approach. Cooperation is essential between the representatives of social sciences (especially sociology, psychology, pedagogy and economics), sciences on physical culture and health sciences.

\section{Acknowledgments}

We would like to express our sincere gratitude to Maciej Sitkowski (SKN Nicolaus Copernicus Adventure Club in Toruń) for their help and involvement in the research project "Behaviors and preferences of LGBT Tourism in Poland".

\section{References}

16th Annual Gay \& Lesbian Tourism Report: Exploring Tourism and Hospitality Opportunities in the Gay and Lesbian Marketplace 2011-2012 (2011), Community Marketing, Inc., http://www.gayadnetwork.com/files/CMItourismstudy2011.pdf (referred 4/06/2015).

Alegre, J., Mateo, S., Pou, L. (2010), An analysis of households' appraisal of their budget constraints for potential participation in tourism, Tourism Management, Vol. 31, No. 1, pp. 45-56.

Badgett, M. V. L. (2000), The myth of gay and lesbian affluence, Gay \& Lesbian Review Worldwide, Vol. 7, No. 2, pp. 22-25.

Barrett, D. C., Pollack, L. M. (2005), Whose Gay Community? Social Class, Sexual SelfExpression, and Gay Community Involvement, Sociological Quarterly, Vol. 46, pp. 437-456.

Batorski, D. (2013), Polacy wobec technologii cyfrowych - uwarunkowania dostępności sposobów korzystania. Diagnoza Społeczna 2013. Warunki i Jakość Życia Polaków Raport, Contemporary Economics, Vol. 7, pp. 317-341.

Benotsch, E. G., Martin, A. M., Espil, F. M., Nettles, C. D., Seal, D. W., Pinkerton, S. D. (2011), Internet Use, Recreational Travel, and HIV Risk Behaviors in Men Who Have Sex With Men, Journal of Community Health, Vol. 36, No. 3, pp. 398-405.

Biernat, E., Lubowiecki-Vikuk, A. P. (2012), Tourist activity among urban singles in view of socio-demographic factors, Studies in Physical Culture and Tourism, Vol. 19, No. 2, pp. 86-93.

Binnie, J., Valentine, G. (1999), Geographies of sexualities - a review of progress, Progress in Human Geography, Vol. 23, No. 2, pp. 175-187. 
Borzyszkowski, J. (2005), Polityka turystyczna państwa, Koszalin: Wydawnictwo Uczelniane Politechniki Koszalińskiej.

Borzyszkowski, J. (2011), Destination Management Organisations (DMO) - nowoczesne struktury organizacyjne w turystyce, In: Jalinik, M., Sierpińska, A., Nowe wyzwania gospodarki turystycznej na poziomie lokalnym, regionalnym $i$ międzynarodowym (pp. 236-256), Białystok: Oficyna Wydawnicza Politechniki Białostockiej.

Borzyszkowski, J. (2012), Społeczność LGBT (lesbian, gay, bisexual \& transgender) atrakcyjny segment współczesnego rynku turystycznego, Studia Periegetica, Vol. 7, pp. 131-145.

Borzyszkowski, J. (2014), Theoretical Approaches to Destination Management, Ekonomická revue cestovného ruchu, Vol. 47, No. 2, pp. 108-118.

Clift, S., Forrest, S. (1999), Gay men and tourism: destinations and holiday motivations, Tourism Management, Vol. 20, No. 5, pp. 615-625.

Crompton, J. L. (1979), Motivations for pleasure vacations, Annals of Tourism Research, Vol. 6, No. 4, pp. 408-424.

Coon, D. R. (2012), Sun, Sand, and Citizenship: The Marketing of Gay Tourism, Journal of Homosexuality, Vol. 59, No. 4, pp. 511-534.

Cooper, C., Fletcher, J., Fyall, A., Gilbert, D., Wanhill, S. (2005), Tourism: Principles and practice, Essex: Prentice Hall.

Dioli, I. (2011), From Globalization to Europeanization - And Then? Transnational Influences in Lesbian Activism of the Western Balkans, Journal of Lesbian Studies, Vol. 15, No. 3, pp. 311-323.

Dixon, L. J. (2015), Black swan, white masks: Contesting cosmopolitanism and double misrecognition in a gay tourist town, Sexualities, Vol. 18, No. 1-2, pp. 37-56.

Ferreira, E. (2013), De-Centring Western Sexualities: Central and Eastern European Perspectives, Gender, Place \& Culture: A Journal of Feminist Geography, Vol. 20, No. 1, pp. 132-134.

Fojtová, S. (2011), Czech Lesbian Activism: Gay and Lesbian Parental Rights as a Challenge to Patriarchal Marriage, Journal of Lesbian Studies, Vol. 15, No. 3, pp. 356-383.

Global Report on LGBT Tourism (2010), AM Reports, Volume three, World Tourism Organization (UNWTO).

Grossmann, A. (1998), The case for a place of their own: Queer youth and urban space, In: Aitchison, C., Jordan, F., Gender, space and identity. Leisure, culture and commerce (pp. 127-136), Brighton: LSA.

Hanefors, M. (2010), Contemporary tourist behavior: yourself and others as tourists, Tourism Management, Vol. 31, No. 6, pp. 962-963.

Haslop, C., Hill, H., Schmidt, R A. (1998), The Gay Lifestyle - Spaces for a Subculture of Consumption, Marketing Intelligence \& Planning, Vol. 16, No. 5, pp. 318-326.

Hindle, P. (1994), Gay communities and gay space in the city, In: Whittle, S., The margins of the city: Gay men's urban lives (pp. 7-25), Hants, Arena: Ashgate Publishing Limited.

Hughes, H. L. (1997), Holidays and homosexual identity, Tourism Management, Vol. 18, No. 1, pp. 3-7.

Hughes, H. L. (2002), Gay men's holiday destination choice: a case of risk and avoidance, International Journal of Tourism Research, Vol. 4, pp. 299-312.

Hughes, H. L. (2003), Marketing gay tourism in Manchester: New market for urban tourism or destruction of 'gay space'? Journal of Vacation Marketing, Vol. 9, No. 2, pp. 152163.

Hughes, H. L. (2005), A Gay Tourism Market: Reality or Illusion, Benefit or Burden? Journal of Quality Assurance in Hospitality \& Tourism, Vol. 5, No. 2/3/4, pp. 57-74.

Hughes, H. L. (2006), Pink Tourism: Holiday of gay men and lesbians, Wallingford: CABI. 
Hughes, H. L., Deutsch R. (2010), Holidays of older gay men: Age or sexual orientation as decisive factors? Tourism Management, Vol. 31, pp. 454-463.

Jędrysiak, T. (2008), Turystyka kulturowa, Warszawa: PWE.

Khan, R. M. (2013), Travel Motivations of Gay and Lesbian Tourists, A Qualitative Inquiry, University of Delaware.

Köllen, T., Lazar, S. (2012), Gay Tourism in Budapest: An Exploratory Study on Gay Tourists' Motivational Patterns for Traveling to Budapest, American Journal of Tourism Management, Vol. 1, No. 3, pp. 64-68.

Kuchar, R., Švab, A. (2014), The Only Gay in the Village? Everyday Life of Gays and Lesbians in Rural Slovenia, Journal of Homosexuality, Vol. 61, No. 8, pp. 1091-1116.

Kulpa, R. (2014), Western leveraged pedagogy of Central and Eastern Europe: discourses of homophobia, tolerance, and nationhood, Gender, Place \& Culture: A Journal of Feminist Geography, Vol. 21, No. 4, pp. 431-448.

LaSala, M. C., Revere, E. J. (2011), "It Would Have Been Impossible Before” Reflections on Current Gay Life in Estonia, Journal of Homosexuality, Vol. 58, No. 3, pp. 427-439.

Lubowiecki-Vikuk, A. P. (2011), Determinanty aktywności rekreacyjno-turystycznej osób samotnych $w$ Wielkopolsce, Poznań: AWF.

Lubowiecki-Vikuk, A. P. (2014), Single senior citizens' praxeological orientation to leisuretime physical activity, In: Flemr, L., Němec, J., Kudláčková, K. (eds.), Physical activity in science \& practice (pp. 105-116), Prague: Karolinum.

Lundberg, D. E. (1971), Why people travel, Cornell Hotel and Restaurant Administration Quarterly, Vol. 11, No. 75, pp. 75-81.

Lück, M. (2005), Destination Choice and Travel Behaviour of Gay Men, Brock University, Department of Recreation and Leisure Studies.

Łaciak, J. (2013), Aktywność turystyczna mieszkańców Polski w wyjazdach turystycznych 2012 roku, Warszawa: Ministerstwo Sportu i Turystyki.

Mathieson, A., Wall, G. (1987), Tourism: Economic, physical, and social impacts, Harlow, Essex, England, Longman Scientific \& Technical.

Melián-González, A., Moreno-Gil, S., Araña, J. E. (2011), Gay tourism in a sun and beach destination, Tourism Management, Vol. 32, No. 5, pp. 1027-1037.

Monterrubio, J. C. (2009), Identity and sex: concurrent aspects of gay tourism, Tourismos: An International Multidisciplinary Journal of Tourism, Vol. 4, No. 2, pp. 155-167.

Morris, E., Carney, M. (2010), Gay tourism: A comparative view between gay pride events and other major events and their impact on a given destination, http://www.marcuscarney.com/images/Gay_Tourism.pdf (referred 19/05/2014).

Otero Paradela, A. B., Alén González, M. E., Domínguez Vila, T. (2014), Turismo LGTB. Unha aproximación ao caso de Galicia, Revista Galega de Economia, Vol. 23, No. 1, pp. 79-98.

Philipp, S. F. (1999), Gay and Lesbian Tourists at a Southern U.S.A. Beach Event, Journal of Homosexuality, Vol. 37, No. 3, pp. 69-86.

Podróże Polaków w 2013 roku. Podstawowe wyniki badań (2014), Warszawa: Ministerstwo Sportu i Turystyki, Activ Group.

Poria, Y. (2006), Assessing Gay Men and Lesbian Women's Hotel Experiences: An Exploratory Study of Sexual Orientation in the Travel Industry, Journal of Travel Research, Vol. 44, pp. 327-334.

Pritchard, A., Morgan, N. J., Sedgely, D., Jenkins, A. K. (1998), Reaching out to the gay tourist: opportunities and threats in an emerging market segment, Tourism Management, Vol. 19, No. 3, pp. 273-282. 
Pritchard, A., Morgan, N. J., Sedgley, D., Khan, E., Jenkins, A. (2000), Sexuality and holiday choices: conversations with gay and lesbian tourists, Leisure Studies, Vol. 19, pp. 267282.

Puar, J. K. (2002), Circuits of Queer Mobility: Tourism, Travel, and Globalization, GLQ: Journal of Lesbian and Gay Studies, Vol. 8, No. 1, pp. 101-137.

Raport o stanie gospodarki turystycznej w latach 2007-2011 (2013), Warszawa: Ministerstwo Sportu i Turystyki.

Rink, B. M. (2013), Que(e)rying Cape Town: Touring Africa's 'gay capital' with the Pink Map, In: Sarmento, J., Brito-Henriques, E., Tourism in the global south: landscapes, identities and development (pp. 65-90), Lisbon: Centre for Geographical Studies.

Roth, T. (2010), The is no 'gay market'. Reaching and serving the diverse U.S. LGBT markets, Travel Gay Canada, 2010 LGBT Tourism Conference.

Stuber, M. (2002), Tourism Marketing Aimed at Gay Men and Lesbians: A Business Perspective, In: Clift, S., Luongo, M., Callister, C., Gay Tourism: Culture, Identity and Sex (pp. 88-124), London \& New York: Continuum.

Southall, C., Fallon, P. (2011), LGBT Tourism, In: Robinson, P., Heitmann, S., Dieke, P. U. C., Research Themes for Tourism (pp. 218-232), CAB International.

Taylor, A. (1997), A queer geography, In: Medhurst, A., Munt, S. R., Lesbian and gay studies: A critical introduction (pp. 3-19), London \& Washington, Cassell.

Verdugo, J. C. L. (2010), Reykjavík as a new gay and lesbian destination, Reykjavík: Faculty of Life and Enviromental Sciences Engineering and Natural Sciences, University of Iceland.

Visser, G. (2003), Gay men, leisure space and South African cities: the case of Cape Town, Geoforum, Vol. 34, No. 1, pp. 123-137.

Visser, G. (2008), The homonormalisation of white heterosexual leisure spaces in Bloemfontein, South Africa, Geoforum, Vol. 39, pp. 1344-1358.

Visser, G. (2010), Leisurely Lesbians in a Small City in South Africa, Urban Forum, Vol. 21, pp. 171-185.

Zając, J. M., Batorski, D. (2009), Metody zwiększania zwrotności w badaniach internetowych, In: Haber, A., Szałas, M., Ewaluacja wobec wyzwań stojacych przed sektorem finansów publicznych (pp. 129-147), Warszawa: PARP. 